\title{
Measurements and receptor modeling of volatile organic compounds in Southeastern Mexico City, 2000-2007
}

\author{
H. Wöhrnschimmel ${ }^{1,2}$, M. Magaña ${ }^{1}$, W. A. Stahel $^{3}$, S. Blanco ${ }^{1}$, S. Acuña ${ }^{4}$, J. M. Pérez ${ }^{1}$, S. González ${ }^{1}$, V. Gutiérrez ${ }^{1}$, \\ S. Wakamatsu ${ }^{5}$, and B. Cárdenas ${ }^{1}$ \\ ${ }^{1}$ Instituto Nacional de Ecología, Mexico City, Mexico \\ ${ }^{2}$ Institute for Chemical and Bioengineering, ETH Zurich, Switzerland \\ ${ }^{3}$ Seminar for Statistics, ETH Zurich, Switzerland \\ ${ }^{4}$ Instituto Politécnico Nacional, Mexico City, Mexico \\ ${ }^{5}$ Ehime University, Matsuyama, Japan
}

Received: 19 January 2010 - Published in Atmos. Chem. Phys. Discuss.: 8 February 2010

Revised: 1 September 2010 - Accepted: 13 September 2010 - Published: 29 September 2010

\begin{abstract}
Ambient samples of volatile organic compounds (VOCs) were measured between 2000 and 2007 in Southeastern Mexico City, quantifying 13 species (ethane, propane, propylene, butane, acetylene, pentane, hexane, heptane, benzene, octane, toluene, nonane, o-xylene). These time series were analyzed for long-term trends, using linear regression models. A main finding was that the concentrations for several VOC species were decreasing during this period. A receptor model was applied to identify possible VOC sources, as well as temporal patterns in their respective contributions. Domestic use of liquefied petroleum gas (LPG) and vehicle exhaust are suggested to be the principal emission sources, contributing together between $70 \%$ and $80 \%$ to the total of quantified species. Both diurnal and seasonal patterns, as well as a weekend effect were recognized in the modelled source contributions. Furthermore, decreasing trends over time were found for LPG and hot soak $(-7.8 \%$ and $-12.7 \%$ per year, respectively, $p<0.01$ ), whereas for vehicle exhaust no significant trend was found.
\end{abstract}

\section{Introduction}

\subsection{The air pollution problem in Mexico City}

The Mexico City Metropolitan Area (MCMA) is one example of rapidly expanding megacities in developing countries. Its population has grown from 1.6 million in 1940 and

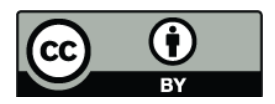

Correspondence to: $\mathrm{H}$. Wöhrnschimmel (henry.woehrnschimmel@chem.ethz.ch)
13.3 million in 1980, to approximately 18.1 million in 2005 (Anzaldo and Barrón, 2009). Along with the number of inhabitants, the air pollution problem also increased, reaching its most severe conditions during the early and mid-1990s (SMA, 2007). Although new technologies and control measures have led to decreasing trends in some air pollutants over the last decade, both suspended particles and ozone still frequently exceed the national standards in many regions of the MCMA. Short episodes of high concentrations of sulphur dioxide $\left(\mathrm{SO}_{2}\right)$ deriving from industrial plumes have also become a local problem in the northern parts of the City (SMA, 2007; De Foy et al., 2007).

Volatile Organic Compounds (VOCs) are a crucial determinant of air quality in Mexico City. Together with nitrogen oxides $\left(\mathrm{NO}_{\mathrm{x}}\right)$, they are responsible for the formation of ozone, which peaks over $200 \mathrm{ppb}$ within the MCMA, and exceeds the national air quality standard (110 ppb for 1-h average) on over half of the days of the year (SMA, 2007). Ozone is thought to cause restricted activity days (i.e. days when employees cannot go to work or children do not attend school due to air pollution induced health effects), and has even been identified as a likely contributor to mortality (Evans et al., 2002). In addition, some VOCs are air toxics, such as benzene and toluene. Benzene has been recognized as a human carcinogen (WHO, 2000), and air quality standards have been established for this compound in several countries. For example, the European Community has set a limit of $5 \mu \mathrm{g} / \mathrm{m}^{3}(9.4 \mathrm{ppbC})$ as an annual mean in order to protect public health (EC, 2000), while Japan set its air quality standard to $3 \mu \mathrm{g} / \mathrm{m}^{3}$ (5.6 ppbC, Japanese Ministry of Environment, 1997).

Published by Copernicus Publications on behalf of the European Geosciences Union. 


\subsection{Previous VOC measurements}

Although VOCs are not yet routinely measured by the Mexico City air quality monitoring network, they have been addressed in several measurement campaigns carried out in Mexico City. One of the longest time series has been determined at three sites over 9 years (1992-2001), measuring 55 VOCs in the morning hours and in selected months of the year. A decreasing trend has been reported for Xalostoc, an industrial site in Northeastern Mexico City. The two other sites, Merced, in the city center with prevailing vehicle emissions, and Pedregal, an affluent residential area in Southern Mexico City, did not show any trends. It is thought that VOC concentrations did not increase - in spite of an augmenting vehicle fleet - due to better fuel efficiency and cleaner vehicle technology (Arriaga et al., 2004).

The composition of VOCs has been characterized in some of the studies, finding that alkanes contribute most to the total VOCs (54-60\%), followed by aromatics (15-26\%) and alkenes (5-18\%) (INE/SMA/UAM, 2006; Apel et al., 2010; Velasco et al., 2007; and references therein). From these groups, aromatics and alkenes are especially important for ozone formation due to their high reactivity, in spite of their lower concentration in ambient air. Formaldehyde and other oxygenated VOCs have also been determined in specific campaigns (Grutter et al., 2005; Volkamer et al., 2005; Apel et al., 2010; Fortner et al., 2009). An analysis of the vertical VOC distribution in the low boundary layer of Mexico City has been reported in Velasco et al. (2008).

In the context of ozone formation, VOC vs. $\mathrm{NO}_{\mathrm{x}}$ sensitivity of the Mexico City air has been discussed as a crucial parameter (Molina et al., 2002) and was the subject of several recent studies (Lei et al., 2007, 2008; Tie et al., 2007; Song et al., 2010). Chemical transport model simulations indicated that ozone formation was VOC limited during the MCMA-2003 campaign (Lei et al., 2007, 2008). Sensitivity analyses of ozone production to precursor emissions under different meteorological conditions during the MCMA-2006/MILAGRO campaign demonstrate that the MCMA urban core region is VOC-limited for all meteorological episodes, while the surrounding areas with relatively low $\mathrm{NO}_{\mathrm{x}}$ emissions can be either $\mathrm{NO}_{\mathrm{x}}$ - or VOC-limited regimes depending on the episode (Song et al., 2010). The analysis of the weekend effect by Stephens et al. (2008) also provided direct empirical evidence for VOC limitation. These results suggest that the controls on VOC emissions would be a more effective way to reduce ozone levels in the urban area, which is consistent with previous results from the MCMA-2003 campaign (Lei et al., 2007, 2008). During the MCMA-2006 campaign, VOC-limitation was even stronger due to reduced $\mathrm{VOC} / \mathrm{NO}_{\mathrm{x}}$ ratios and $\mathrm{VOC}$ reactivities in the estimated emissions. Furthermore, meteorological conditions led to large variations in regime for the area with relatively low $\mathrm{NO}_{\mathrm{x}}$ emissions, implying that emission controls would depend on location and meteorology (Song et al., 2010).
As part of VOC reactivity, the contribution of compounds associated to liquefied petroleum gas (LPG) has been an issue of debate. 8 out of 10 homes in Central Mexico use LPG for heating water and cooking, making Mexico the country with the worldwide highest LPG consumption per capita (SENER, 2009a). Although the LPG related species have low reactivity, they are emitted to the atmosphere in huge amounts, so their importance has been emphasized in several works. The conclusions range from a relatively small effect on ozone formation (Gasca et al., 2004; Jaimes-López et al., 2003; Gamas et al., 2000) to a significant share (Blake and Rowland, 1995), depending on where in the MCMA the experimental data were obtained, and on the methodological approach.

The debate about the role that LPG plays for total VOC concentrations and ozone formation leads almost instantly to the question of other VOC sources' contribution to the total VOC burden. Source apportionment studies have been carried out in the MCMA (Mugica et al., 2002; Wöhrnschimmel et al., 2006; Sosa et al., 2008) using source profiles measured in Mexico City (Mugica et al., 2002; Zavala et al., 2006). The general finding was that vehicle exhaust and the domestic use of LPG are the principal sources, along with the use of solvents.

These results, however, are in contrast with the most recent official emission inventory, where mobile sources (gasolineand diesel-powered) are estimated to contribute $34 \%$ to the total VOC burden, whereas leaking and unburnt LPG only contributes about $11 \%$ (SMA, 2008). Several studies suggest that this and previous inventories underestimate VOC emissions by a factor of 2 or 3 , or that at least alkanes, aromatics and aldehydes are underestimated (West et al., 2004; Arriaga et al., 2004; Lei et al, 2007; 2008; Zavala et al., 2009). Airborne flux measurements supported these hypotheses, indicating that inventories underestimated the emissions of toluene and benzene (Karl et al., 2009). On the other hand, flux measurements at fixed urban sites within the MCMA conclude that the emission inventory actually overestimates the emissions of aromatic VOC species (Velasco et al., 2005; Velasco et al., 2009).

Finally, the toxicity of some VOC species has been addressed in particular by measurements of benzene and toluene. Bravo et al. (2002) report benzene concentrations from grab samples at a condominium and a university campus site of 18.7 and $22.0 \mathrm{ppbC}$, respectively, which is two times higher than the EC limit value. The authors suggest that an air quality standard for benzene is needed in Mexico, followed by control strategies like assuring proper functioning of catalytic converters and vapor recovery systems at gas stations. During the MCMA-2002 and MCMA-2003 campaigns, urban benzene concentrations averaged $19.0 \mathrm{ppbC}$ (Velasco et al., 2007), and during the MILAGRO-2006 an average of $12.2 \mathrm{ppbC}$ was determined at a different urban sites (Apel et al., 2010). 


\subsection{Objective of this study}

The present study provides a unique updated time series of VOC measurements between 2000 and 2007 at one site in Southeastern Mexico City. It not only continues previous measurements, but also covers different seasons of the year and times of the day. The specific objectives of this paper are to analyze the trends in VOC concentrations applying regression analysis, and to assess the importance of potential VOC sources over time by means of a receptor model.

\section{Methods}

\subsection{Sampling and analytical procedure}

VOC grab samples were taken regularly during a 7-year period from July 2000 to June 2007 at the Mexican National Center for Environmental Research and Training (CENICA) in Southeastern Mexico City. The over 21000 samples were evenly distributed across the $24 \mathrm{~h}$ of the day and the 12 months of the year, with each sampling event lasting about 4 minutes.

The sampling site is located at $19^{\circ} 21^{\prime} 29^{\prime \prime} \mathrm{N}, 99^{\circ} 04^{\prime} 19^{\prime \prime} \mathrm{W}$, $2240 \mathrm{~m}$ above mean sea level, on the campus of the Autonomous Metropolitan University Iztapalapa. It lies within a low-income residential neighborhood with one of the highest population densities of the MCMA, and is characterized by mechanical workshops, restaurants, and some small industries (printing, production of packaging materials and paints). At a distance of 1 to $2 \mathrm{~km}$ into each direction, highly trafficked main roads and an urban highway (to the East) pass by the measurement site.

The sample inlet was on the CENICA rooftop at a height of $12.7 \mathrm{~m}$ above ground level. From there, a stainless steel line transferred the air sample to a concentrator, then to a gas chromatograph with a flame ionization detector (GCFID, Hewlett-Packard 6890 Series plus), where the following 13 species were quantified: ethane, propane, propylene, butane, acetylene, pentane, hexane, heptane, benzene, octane, toluene, nonane and o-xylene. Our study was limited to these species by the available gas calibration standard (SAAN Co., containing $1 \mathrm{ppmV}$ of each of the 13 compounds). The analysis was carried out according to the EPA's method TO-14A (EPA, 1999). The $400 \mathrm{~mL}$ air sample was controlled for humidity at $25^{\circ} \mathrm{C}$, pre-concentrated in a multiadsorbent trap packed with tenax, activated alumina and activated carbon. The compounds were thermally desorbed at $250{ }^{\circ} \mathrm{C}$ with helium purge gas, and finally the VOC species were separated in two gas chromatographic columns of $30 \mathrm{~m}$ length each, alumina plot (inner diameter $0.53 \mathrm{~mm}$ ) and methyl silicone (inner diameter $0.5 \mathrm{~mm}$ ) connected in series. The identities of the VOC species were obtained by means of the retention times and areas from the gas calibration standard, using a 10-times dilution mixture.
Total measurement uncertainties were quantified only for benzene, toluene and o-xylene, by determining the respective uncertainties of the calibration curves over a range from 1 to $125 \mathrm{ppbV}$, the calibration gas itself, the analyst, and the instrument. The so derived relative uncertainties were between $2.1 \%$ and $4.2 \%$ of the measured value. The GC-FID method detection level (MDL) was determined for all 13 species separately, by carrying out replicate analysis of a calibrating gas at low concentration levels, resulting in MDL between 0.11 and $0.45 \mathrm{ppbV}$.

The sum of the 13 quantified compounds (from now on denoted as $\Sigma_{13}$ VOC) makes up a major part of all VOC species in the Mexico City air. Compared with other measurements of $55 \mathrm{VOC}$ species at the same sampling site (INE/SMA/UAM, 2006), $\Sigma_{13}$ VOC constituted an average fraction of 50\% when concentrations are expressed as ppbC (such fractions will from now on be denoted as $\mathrm{ppbC} \%$ ).

\subsection{Data analysis}

Descriptive statistics and graphical data analysis, as well as the regression and receptor modeling described in the following subsections, were carried out with the statistical package $R$ version 2.10.0 (R Development Core Team, 2009).

\subsubsection{Regression model}

Regression models were fitted to VOC data, in order to estimate the long-term trend of the different species. As explanatory variables for the linear regression models we used time and month, as shown in Eq. (1):

$\log \left(C_{j}\right)=\alpha_{j}+\beta_{j} \times t+\gamma_{j, m}+\varepsilon_{j}$

where $C_{j}$ are the monthly average concentrations of VOC species $j$ (in ppbC), $t$ is the time in years since 2000, $\gamma_{m}$ is the effect of month $m$ that is introduced to improve the precision of the results, and $\varepsilon$ is the error term, modeled as an autoregressive time series of order 5. $\alpha$ is the intercept of the regression equation, whereas the trend is given by $\beta$ and translates to a yearly rate of change by the formula $e^{\beta}-$ 1. The assumption of linearity was verified by testing the significance of a quadratic term $\beta_{j}{ }^{\prime} \times t^{2}$, which turned out to be insignificant in most cases.

Since trends might vary for different times of the day, an analysis with the hour of the day and its interaction with time included in the model was also performed.

More models were tested that are not shown here, using hourly measurements instead of monthly averages, and including the temperature, the wind speed, and the daily and weekly cycle as explanatory variables. This led to rather complex models giving information about the dependence of the VOC concentrations on meteorology and cyclic patterns. However, no additional benefit was gained for the interpretation of the long-term trends, so these results will be reported elsewhere. 


\subsubsection{Receptor model}

A Chemical Mass Balance (CMB) model was used to analyze the contributions of different potential emission sources to the sum of the 13 quantified compounds ( $\Sigma_{13}$ VOC).

In general, a CMB model correlates previously determined source profiles to measured receptor concentrations, solving the multiple regression equation

$\boldsymbol{C}_{t}=\mathbf{F} \times \boldsymbol{S}_{t}+\boldsymbol{\varepsilon}_{t}$

where $\boldsymbol{C}_{t}$ is the vector of the VOC species' concentrations quantified in one sample taken at time $t, \mathbf{F}$ is the source profile matrix, $\boldsymbol{S}_{t}$ is the source contribution vector, and $\boldsymbol{\varepsilon}_{t}$ is the error vector. The source profile matrix $\mathbf{F}$ is composed of previously measured source profile vectors, with each vector describing the relative contents of VOC species (in ppbC\%) from the respective source. The source contribution vector, which is the unknown of this equation, is the absolute contribution of each source to the total measured ambient VOC concentrations (in ppbC). For each observation, this multiple linear regression problem is solved for $\boldsymbol{S}_{t}$ by minimizing the sum of squares of the error vector. Measurement uncertainties of both receptor concentrations and emission profiles are an essential part of the model, since they are used to assign less weight to measurements close to detection limit and to calculate the standard error of the source contribution estimates. The resulting model fits can then be evaluated by a set of model performance parameters, such as the values for $R^{2}$, the reduced $\chi^{2}$, the ratio of modeled to measured mass, the standard error of the source contribution with its corresponding t-statistics, and its projection into the eligible space (US-EPA, 2004).

Some essential assumptions of the CMB model are that the source profiles are constant in time, that there is negligible chemical transformation during the transport from the emission source to the receptor site, and that no unknown emission source contributes significantly to the concentrations at the receptor site. Furthermore, linear independence of the source profile, as well as random, uncorrelated and normally distributed measurement uncertainties are a condition for valid results of CMB.

Currently, the most widespread version of this model is CMB8.2 (US-EPA, 2004). For our analysis, however, the model was implemented in the statistical package $R$, including beside the features of the US-EPA software a more versatile algorithm to select the best fit according to the above described performance parameters. In particular, this algorithm solves Eq. (2) for a user defined range of different combinations of sources and fitting species before returning the ideal solution. This makes it possible to automatically analyze large data sets, and avoids the need to combine sources and species for each sample in a process of trial and error. An example of the typical model output is given in the Supplementary Information.
The emission profiles used in our analysis covered emissions related to LPG usage (like evaporative losses or LPG that remains unburned during incomplete combustion), vehicle exhaust (EXHAUST), vaporized hot soak from the heat of motor engines (HOTSOAK), and solvent use (SOLVENT). For each category, between 1 and 4 different profiles were used, most of them measured in Mexico City between 1996 and 1998 (Vega et al., 2000; Mugica, 1999, Mugica et al., 2002). Also some newer profiles for vehicle exhaust that were determined during 2008 in a tunnel study in the City of Guanajuato, Mexico (unpublished) were included in the EXHAUST category, in order to account for recent changes in fuel characteristics and vehicle technology, like the decreasing share of vehicles without a catalytic converter. All source profiles are provided in the Supplementary Information, together with their uncertainties and background information on the new vehicle exhaust profiles. The inclusion of other potential profiles did not contribute to improving the reported model results.

As receptor concentrations, we selected night, morning, and evening averages of the above described species, omitting propylene and o-xylene because of their high photochemical reactivities. From the remaining compounds, the model was allowed to omit up to one further compound, if this improved the fit. Night averages were calculated for each day from samples with all species quantified that were taken between 01:00 and 04:00. Accordingly, morning averages corresponded to samples taken between 06:00 and 09:00, and evening averages to samples between 18:00 and 21:00. The uncertainties for these receptor concentrations were calculated according to Eq. (3):

$\sigma\left(C_{t}\right)=\left[(2 \times \mathrm{MDL})^{2}+\left(U_{\text {rel }} \times C_{t}\right)^{2}\right]^{1 / 2}$

where $\sigma\left(C_{t}\right)$ is the vector of root mean square errors for the quantified species' concentrations $C_{t}$ in one sample taken at time $t, \mathrm{MDL}$ is the compound specific method detection limit for the GC-FID, and $U_{\text {rel }}$ is the relative measurement uncertainty (estimated here to be $4 \%$ for all species, see also Sect. 2.1).

For the final results we selected only model fits with acceptable performance measures, according to the criteria given in US-EPA (2004): $R^{2} \geqq 0.8, \chi^{2} \leqq 2,80 \% \leqq$ modeled to measured mass ratio $\leqq 120 \%$, standard errors $\leqq 1 / 2$ times the source contribution estimate, and projection into eligible space for all sources $\geqq 0.95$. The descriptive statistics on this selection of model fits is shown in Table 3 .

The results of the CMB model were used to describe the relative importance of the potential sources, and to identify temporal patterns in absolute source contributions. Longterm trends were examined in analogy to the regression analysis for individual VOCs. 


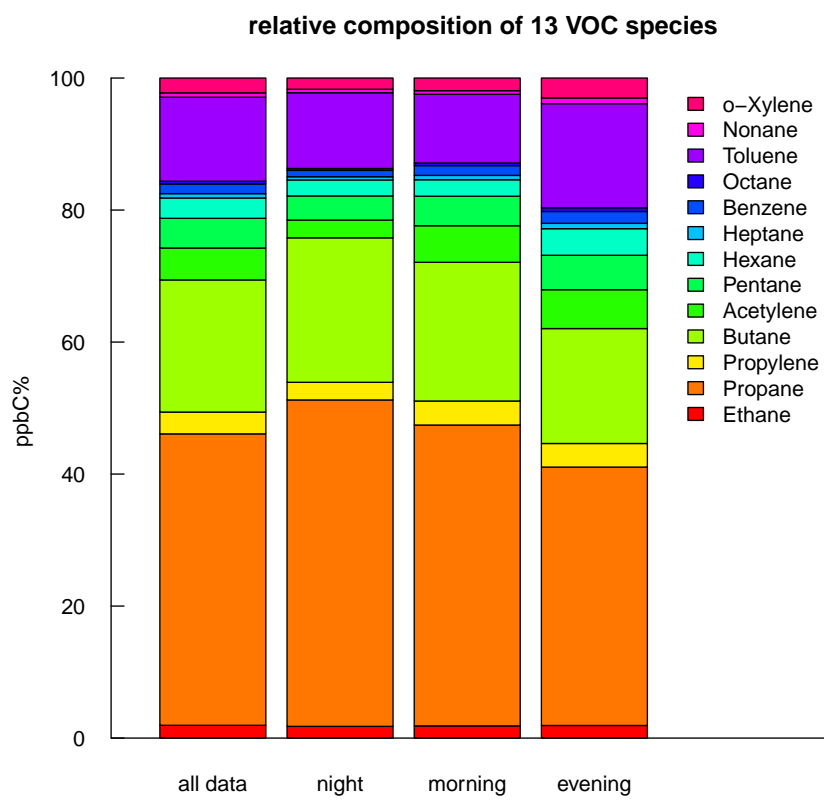

Fig. 1. Relative composition of 13 VOC species in $\mathrm{ppbC}$ for all data (00:00-24:00) and during selected time intervals (night: 01:0004:00; morning: 06:00-09:00; evening: 18:00-21:00). Only samples with all species quantified.

\section{Results and discussion}

\subsection{VOC concentrations}

In Table 1, descriptive statistics are given for each of the quantified VOCs for the whole measurement period from 2000 to 2007. The relative composition for all data and during selected time intervals is shown in Fig. 1. It becomes clear that propane and butane are the major components of the VOC mixture at all times of the day, with mean concentrations of $241.5 \mathrm{ppbC}$ and $108.6 \mathrm{ppbC}$, respectively, followed by toluene, with $70.3 \mathrm{ppbC}$. The average annual benzene concentration of $7.9 \mathrm{ppbC}$ is close to the European limit value of $9.4 \mathrm{ppbC}$. Propylene, the most reactive species, has a mean concentration of $18.1 \mathrm{ppbC}$, which is higher by a factor of two and more than in other urban areas where propylene air concentrations have been reported (Nguyen et al., 2009; Tang et al., 2007; Mohamed et al., 2002; Dollard et al., 2007). These results are similar to previous measurements carried out at different sites in Mexico City (INE/SMA/UAM, 2006; Velasco et al., 2007; Apel et al., 2010). In particular, there is very good agreement with 24-h samples taken at the same site during 2005 and 2006 (INE/SMA/UAM, 2006).

In Fig. 2, time series are shown for $\Sigma_{13}$ VOC, propane, benzene and toluene. Beside a diurnal variability of one to two orders of magnitude, a cyclic annual pattern can be inferred, and will be discussed later in this section. Longer gaps in the data exist in 2002 for reasons of maintenance of
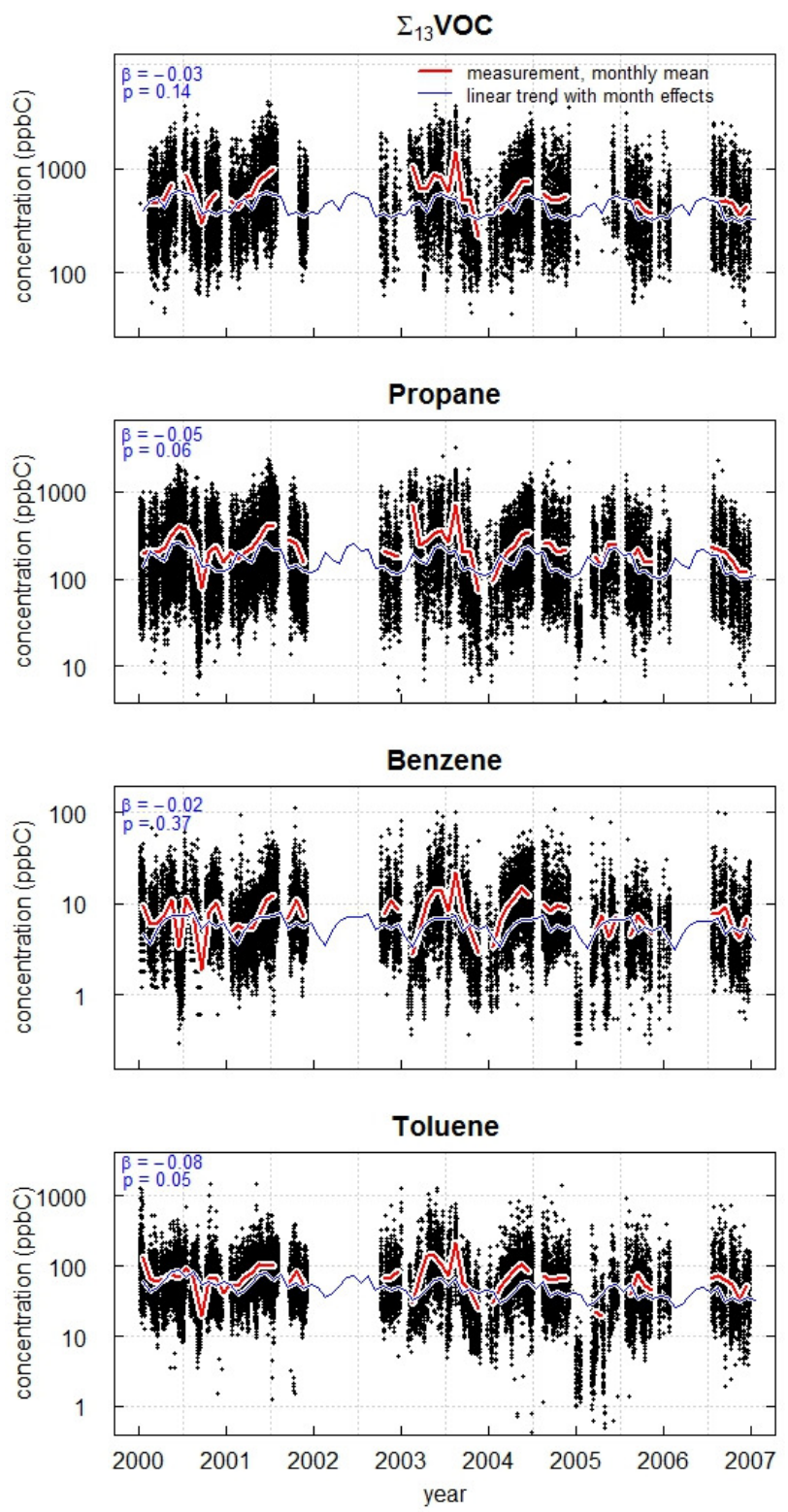

Fig. 2. Time series, monthly means and linear trend with month effects of $\Sigma_{13}$ VOC, propane, benzene and toluene from 2000 to 2007.

the GC-FID, and in 2006, when the analytical method was certified.

Figure 3 shows in more detail the diurnal cycle of $\Sigma_{13}$ VOC, propane, benzene and toluene. Highest concentrations appear between 06:00 and 09:00 and to a lesser extent after 21:00. The average benzene peak reaches $10 \mathrm{ppbC}$ in the morning, with high concentrations over several hours. These peaks can also be observed in the other quantified species (provided in the Supplementary Information), indicating a general pattern of increased emission related activities in the morning and in the evening, like traffic rush hours 
Table 1. Descriptive statistics of VOC measurements from 2000 to 2007 for each of the quantified species. Concentrations in ppbC.

\begin{tabular}{lrrrrrr}
\hline & $n$ & Mean & Median & Standard Dev. & Percentile .05 & Percentile .95 \\
\hline Ethane & 20251 & 10.8 & 8.5 & 8.0 & 2.4 & 26.3 \\
Propane & 21188 & 241.5 & 157.2 & 243.4 & 34.3 & 734.3 \\
Propylene & 19356 & 18.1 & 11.7 & 25.5 & 2.1 & 53.0 \\
Butane & 21138 & 108.6 & 72.4 & 105.7 & 16.1 & 324.8 \\
Acetylene & 20973 & 26.6 & 18.2 & 26.2 & 4.2 & 77.2 \\
Pentane & 21127 & 25.2 & 16.5 & 31.8 & 4.5 & 70.9 \\
Hexane & 20765 & 17.5 & 10.7 & 23.1 & 2.0 & 55.3 \\
Heptane & 20700 & 3.9 & 2.5 & 5.8 & 0.6 & 11.3 \\
Benzene & 20950 & 7.9 & 5.8 & 7.4 & 1.3 & 21.6 \\
Octane & 19495 & 2.6 & 1.7 & 5.5 & 0.6 & 6.3 \\
Toluene & 20848 & 70.3 & 50.3 & 74.9 & 11.2 & 188.1 \\
Nonane & 19507 & 3.8 & 2.4 & 6.9 & 0.6 & 9.7 \\
o-Xylene & 19545 & 12.0 & 8.0 & 17.3 & 1.7 & 33.3 \\
$\Sigma_{13}$ VOC & 15777 & 575.9 & 428.1 & 472.3 & 131.2 & 1531.3 \\
\hline
\end{tabular}

Table 2. Linear regression for all VOC species.

\begin{tabular}{|c|c|c|c|c|c|c|}
\hline & \multirow{2}{*}{$\begin{array}{l}\text { Intercept } \\
\alpha\end{array}$} & \multicolumn{3}{|c|}{ Time } & \multirow{2}{*}{$\begin{array}{l}\text { Month } \\
p\end{array}$} & \multirow{2}{*}{$\begin{array}{r}\text { Yearly rate } \\
\text { of change }(\%)\end{array}$} \\
\hline & & $\beta$ & SE & $p$ & & \\
\hline Ethane & 2.43 & -0.005 & 0.023 & 0.843 & $0.010 * *$ & -0.50 \\
\hline Propane & 5.90 & -0.048 & 0.025 & 0.058 & $0.029 *$ & -4.69 \\
\hline Propylene & 3.33 & +0.014 & 0.053 & 0.791 & 0.427 & +1.41 \\
\hline Butane & 4.99 & -0.041 & 0.020 & $0.047 *$ & 0.068 & -4.02 \\
\hline Acetylene & 3.74 & -0.067 & 0.016 & $0.000^{* * *}$ & $0.011^{*}$ & -6.48 \\
\hline Pentane & 3.32 & -0.063 & 0.051 & 0.220 & $0.024 *$ & -6.11 \\
\hline Hexane & 3.21 & -0.135 & 0.055 & $0.017 *$ & 0.340 & -12.63 \\
\hline Heptane & 1.82 & -0.028 & 0.027 & 0.299 & 0.145 & -2.76 \\
\hline Benzene & 2.32 & -0.024 & 0.027 & 0.377 & 0.215 & -2.37 \\
\hline Octane & 1.42 & -0.052 & 0.031 & 0.093 & 0.519 & -5.07 \\
\hline Toluene & 4.62 & -0.077 & 0.038 & 0.052 & 0.219 & -7.41 \\
\hline Nonane & 1.69 & -0.100 & 0.047 & $0.037 *$ & 0.669 & -9.52 \\
\hline o-Xylene & 2.88 & -0.123 & 0.056 & $0.034 *$ & 0.061 & -11.57 \\
\hline$\Sigma_{13} \mathrm{VOC}$ & 6.69 & -0.030 & 0.020 & 0.144 & $0.029 *$ & -2.96 \\
\hline
\end{tabular}

$\alpha, \beta=$ regression coefficients, $\mathrm{SE}=$ standard error, $p=$ level of significance of coefficients. The $\mathrm{p}$-value is represented as follows: $p<.001^{* * *}, p<.01^{* *}, p<.05^{*}$.

and domestic water heating. In addition, the reduced vertical mixing of the atmosphere at these times contributes to increased concentrations. Solvent related compounds (like hexane, but also toluene) show less pronounced peaks, since their emissions are more uniformly distributed along the day, with higher evaporation around midday. These general characteristics of the diurnal VOC cycles have been measured also at different urban sites during the MCMA-2003 and MILAGRO-2006 campaigns (Velasco et al., 2007; Fortner et al., 2009).

Linear regression models were applied to determine possible long-term trends of ambient VOC concentrations, according to Eq. (1). The resulting regression parameters, together with their standard errors and significance are shown in Table 2 , and the modeled curves including the month effects are added to Fig. 2. Over the 7-years measurement period, several species showed significant negative trends, namely butane, acetylene, hexane, nonane and oxylene. Other species had negative regression coefficients, although they were not significant. For example, toluene decreased by about $7.4 \%$ annually ( $p=0.052$ ), whereas benzene showed no trend.

The modeled month effects indicate the cyclic annual pattern of VOC concentrations: highest concentrations occur between November and February, which in Mexico City corresponds to the dry-cold season, characterized by thermal inversions and high pressure systems. During the drywarm season (March to May) and the rainy season (June to October), concentrations are lower. Differences between the dry-warm and the rainy seasons are thought to depend on compound-specific physicochemical properties and 
Table 3. Descriptive statistics on CMB model performance parameters for selected fits.

\begin{tabular}{lrrrr}
\hline & $n$ & $R^{2}$ & $\chi^{2}$ & Mass\% \\
\hline Night (01:00-04:00) & $650(689)$ & $0.97 \pm 0.04$ & $0.5 \pm 0.3$ & $94.9 \pm 7.0$ \\
Morning (06:00-09:00) & $665(726)$ & $0.96 \pm 0.04$ & $0.5 \pm 0.4$ & $94.9 \pm 6.8$ \\
Evening (18:00-21:00) & $522(696)$ & $0.96 \pm 0.04$ & $0.5 \pm 0.4$ & $96.5 \pm 8.9$ \\
\hline Total & $1837(2111)$ & $0.96 \pm 0.04$ & $0.5 \pm 0.4$ & $95.4 \pm 7.5$ \\
\hline
\end{tabular}

$n=$ number of fits that comply with performance criteria (in parentheses the maximum number of fits), average $R^{2}, \chi^{2}$, and Mass $\%$, with their respective standard deviations.

Table 4. Linear regression for all source contributions.

\begin{tabular}{lrrrlll}
\hline & $\begin{array}{r}\text { Intercept } \\
\alpha\end{array}$ & $\beta$ & Time & Month & $\begin{array}{r}\text { Yearly rate } \\
\text { of change (\%) }\end{array}$ \\
\hline LPG & 5.80 & -0.081 & 0.024 & $0.002 * *$ & $0.000^{* * *}$ & -7.8 \\
EXHAUST & 5.50 & -0.013 & 0.024 & 0.585 & 0.079 & -1.3 \\
HOTSOAK & 2.80 & -0.136 & 0.026 & $0.000^{* * *}$ & $0.021^{*}$ & -12.7 \\
SOLVENT & 3.15 & -0.018 & 0.030 & 0.554 & 0.070 & -1.8 \\
\hline
\end{tabular}

$\alpha, \beta=$ regression coefficients, $\mathrm{SE}=$ standard error, $p=$ level of significance of coefficients. The $\mathrm{p}$-value is represented as follows: $p<.001^{* * *}, p<.01^{* *}, p<.05^{*}$.

source-specific seasonal variations in emissions. A deeper analysis of these relations is beyond the scope of the present work.

Trends have been analyzed also in function of the time of the day. The results are added to Fig. 3 (see also Supplementary Information), showing the modeled average concentration for each hour for July 2000 and June 2007, respectively. Reductions did not occur homogeneously over the day or for each VOC species in the same way. For example, propane reductions occurred mainly during the night, whereas benzene and toluene decreased most significantly during the morning hours and at noon, respectively. These differences give further evidence that different sources with distinct timely emission patterns control the VOC species' atmospheric concentrations. Possible temporal changes in photochemical reactivity of the Mexico City atmosphere might also have contributed to the observed time- and compound-specific trends.

\subsection{Source apportionment}

Figure 4 illustrates the modelled relative contribution of different emission sources to the measured VOC concentrations at different times of the day. It becomes clear that LPG and vehicle exhaust are the principal sources. At night, LPG is dominant with a median contribution of $54 \%$, whereas vehicle exhaust adds $32 \%$ to $\Sigma_{13}$ VOC. During the day, the relative contribution of LPG decreases, down to a median share of $27 \%$ in the evening, whereas vehicle exhaust becomes more important, increasing up to $62 \%$. This model result reflects leakages from stationary LPG tanks being a continuous source, especially accumulating within the noc- turnal stable boundary layer, while vehicle exhaust emissions occur mainly during the day. Solvent use and hot soak emissions contribute together only between $3 \%$ and $11 \%$ to the quantified species during the course of the day.

These findings confirm previous receptor modelling studies in the MCMA, which in general have identified LPG and vehicle exhaust as the dominant sources: Sosa et al. (2008) report LPG and vehicle exhaust contributions at a University campus site in Southwestern Mexico City of 52\% and 25\% during the morning hours, respectively. Mugica et al. (2002) find vehicle exhaust to be more abundant than LPG at three different sites (industrial, commercial and high-income neighbourhood, respectively). The differences among these results reflect the regional variability of source contributions within the urban area. The latest emission inventory (SMA, 2008) takes this fact into consideration, presenting gridded emissions over the MCMA. However, this emission inventory still fails to recognize the high contribution of LPG to total VOC concentrations.

In Fig. 5 the inter-annual variations of absolute source contributions of LPG and vehicle exhaust are shown. The modelled trend according to the regression analysis is also added, and the corresponding numerical results are given in Table 4, along with results for the other sources. There was a significant trend for LPG, with an annual decrease rate of $7.8 \%(p<0.01)$. Hot soak emissions decreased by annually $12.7 \%(p<0.001)$. Although hot soak contributes only a minor fraction to the quantified VOC species (Fig. 4), the result might be an indicator for an improved evaporative emissions control in newer vehicles. The annual decrease in vehicle exhaust of $1.3 \%$ was not significant, although the recent 

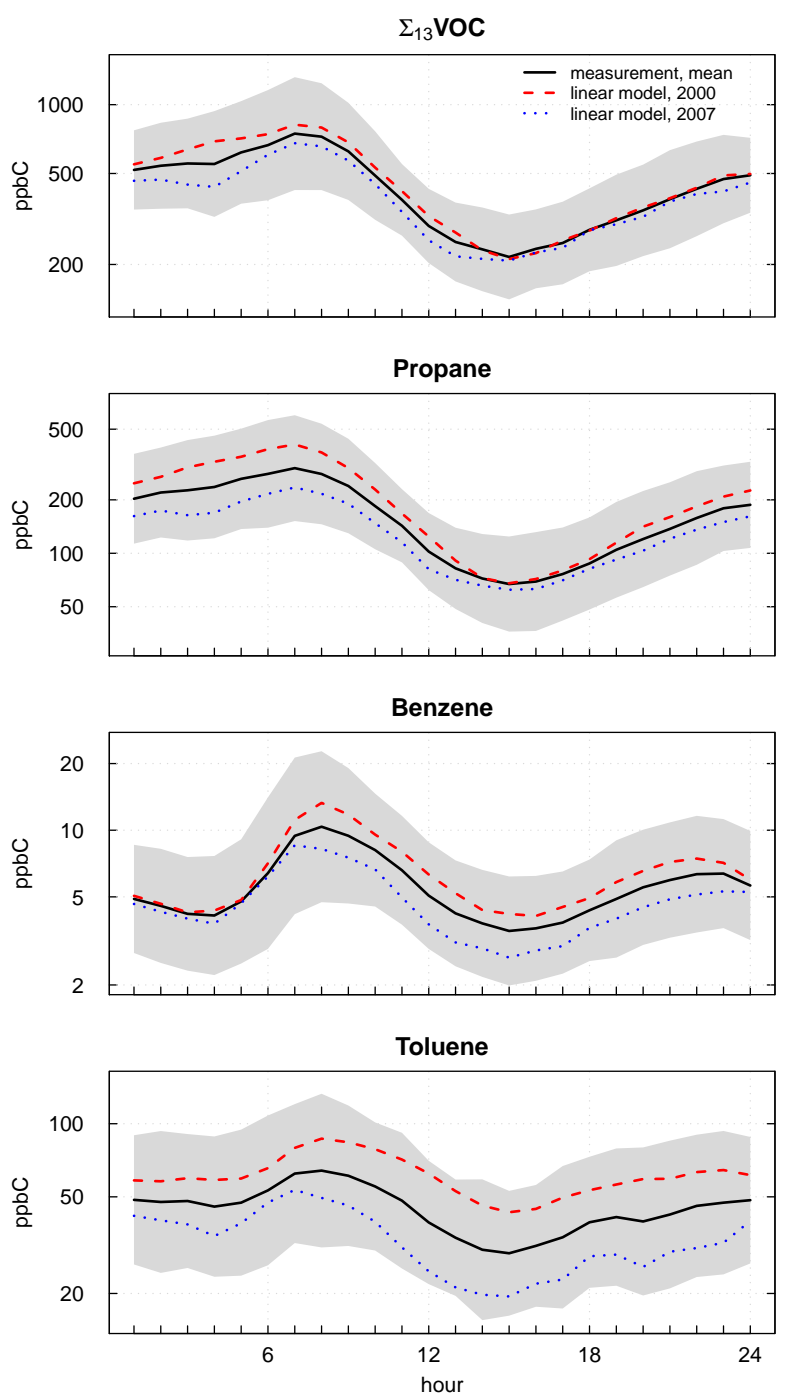

Fig. 3. Diurnal variation of $\Sigma_{13}$ VOC, propane, benzene, and toluene. Shown are mean concentrations with standard deviations (solid line with grey shadow), as well as the modelled values for July 2000 and June 2007 (dotted lines).

literature suggests such a trend for vehicle emissions: Zavala et al. (2009) report a decrease of measured on-road emission factors for selected aldehydes and aromatics between 2003 and 2006; for cruising conditions, the reductions ranged from $25 \%$ to $58 \%$ over the three years span, whereas for stop-andgo conditions and heavy traffic, the reductions were smaller. The discrepancy between these results and our study is attributed to the wider range of aromatics and aldehydes included in Zavala et al. (2009).

Also an intra-annual cycle is evident from the month effects of the linear model (Fig. 5), indicating higher absolute source contributions during the dry-cold season. This is in analogy to the higher VOC concentrations observed at this time of the year (Fig. 2). LPG contribution is about $60 \%$

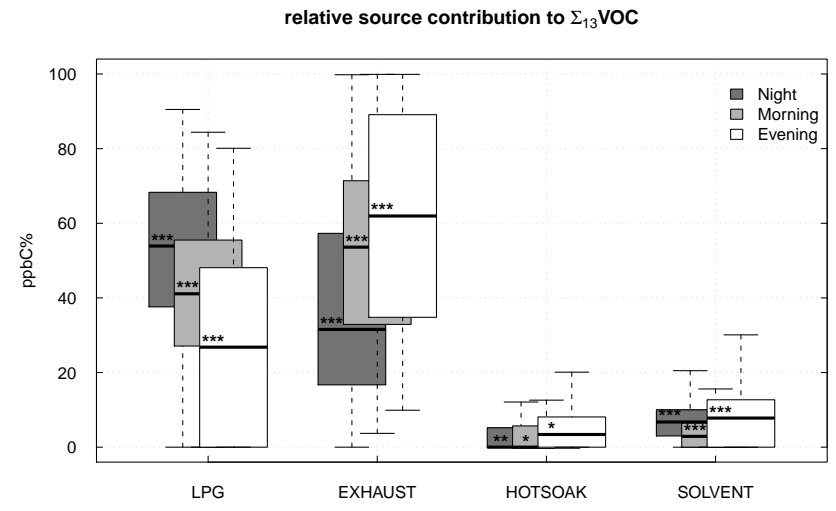

Fig. 4. Relative source contributions at night (01:00-04:00), in the morning (06:00-09:00), and in the evening (18:00-21:00). The asterisks within the boxes indicate the significance with which the respective source was detectable, according to the median t-value of the modeled source contributions: $p<.001^{* * *}, p<.01^{* *}, p<$ $.05^{*}$.
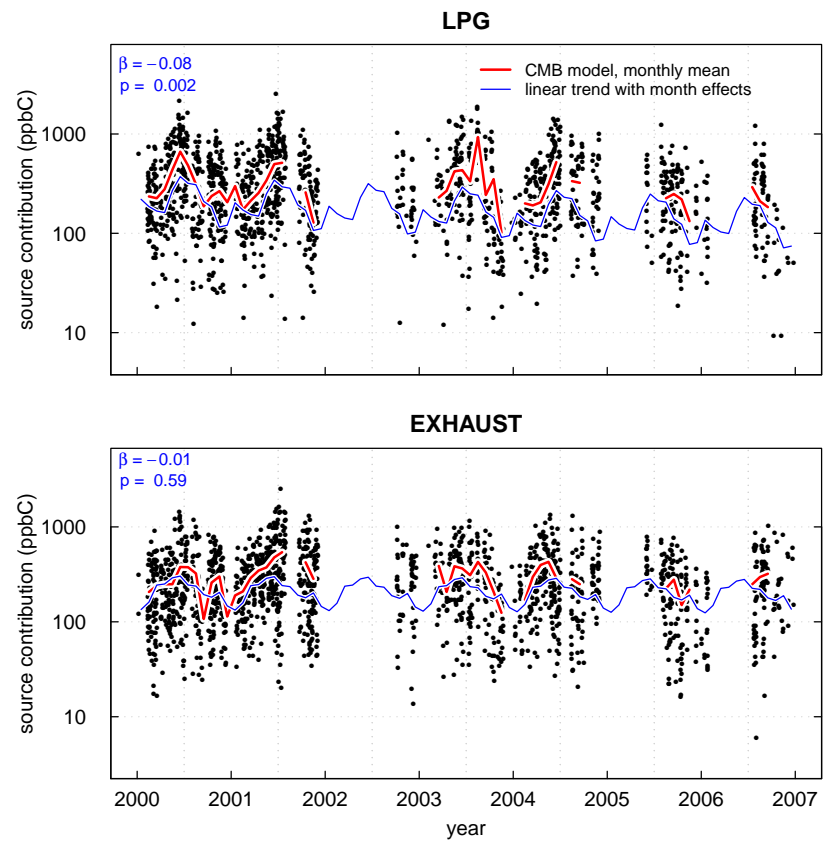

Fig. 5. Time series, monthly means and linear trend with month effects of the absolute LPG and vehicle exhaust source contributions.

higher from November to February than in the period from July to October; vehicle exhaust is about $31 \%$ higher ( $p \leq$ 0.05 and $p=0.08$, respectively; paired Wilcoxon signed ranked test on monthly averaged source contributions). If we assume, as a first approximation, that LPG increases due to both the reduced mixing layer height and higher LPG consumption for water heating, whereas vehicle exhaust increases only due to meteorological effects, we can estimate that during the dry-cold season the usage of LPG increases by about $22 \%$. This can be compared to national sales data 
for LPG (SENER, 2009b), which over the last decade have been about 15\% higher in the months from September to January than in the 4 previous months.

Finally, a weekend effect also becomes evident in the vehicle exhaust contribution: we find less emissions on Sunday mornings in comparison with working days, by about $32 \%$, ( $p<0.001$; paired Wilcoxon signed ranked test, using averaged source contributions from Monday to Friday of each week). Velasco et al. (2009) report similar values for weekend decreases in alkene and $\mathrm{C}_{2}$-benzene fluxes. The reason is that for most people economic activities and related vehicle use start later in the day or are suspended on Sundays. During Sunday night from 01:00 to 04:00, however, the vehicle exhaust contribution is higher by about $17 \%(p<0.05)$. This effect has been observed also for VOC fluxes (Velasco et al., 2009) and criteria air pollutants (Stephens et al., 2008) in Mexico City and it has been described as the "party-effect", since higher vehicle emissions derive from abundant social and economic activities during Saturday nights.

\section{Conclusions}

In this paper, a time series of 7 years of VOC measurements in ambient air in Southeastern Mexico City has been analyzed. The average composition of the 13 quantified VOC species was in agreement with previous measurements, and indicated a strong presence of alkanes and aromatics. In particular, carcinogenic species like benzene were measured at levels close to international limit values, which suggests the occurrence of health effects in the population from past and present exposure. Also reactive VOC species were present at high concentrations, compared to urban areas in other countries. A receptor model used for source apportionment showed that vehicle exhaust and LPG are the dominant sources contributing to the measured species. Trend analyses indicated a decrease in some of the VOC species, which correspond to a reduction of $7.8 \%$ and $12.7 \%$ annually for LPG and hot soak emissions, respectively. No increase was evident for any VOC species or source contribution, in spite of a growing population and a steadily augmenting vehicle fleet.

These results confirm a positive effect of the efforts that have been placed into improving vehicle technology and fuel quality in Mexico City, as well as a stricter exhaust monitoring program. Nevertheless, neither benzene nor $\Sigma_{13} \mathrm{VOC}$ decreased significantly, which implies that additional measures are necessary to head towards a healthier environment for Mexico City's inhabitants, at least in specific parts of the urban area. This is true especially in the context of a growing demand for private mobility and a developing market for low-cost vehicles. Among other strategies, the public transport needs to be further developed in quality and coverage. Regarding the still high emissions of LPG, we encourage a maintenance program for domestic equipment.
Future research is needed in order to overcome the limitations of the present study. Measurements at the CENICA site should be continued in order to detect future potential changes in VOC concentrations, including beside the 13 compounds other critical VOC species. Also the establishment of additional long-term monitoring sites would be desirable, in order to address the inhomogeneity of a big urban area such as the MCMA. There is a need to determine recent emission profiles in Mexico City, including also industrial sources. In this way, future receptor modelling studies could provide a more accurate and complete picture on source contributions in Mexico City and support the development of air quality management strategies. In this context, also a reanalysis of the data presented by Arriaga et al. (2004), where trends have been discussed only on a basis of the total concentration of 55 VOC species, could give additional insight into how measures implemented in the past affected the concentrations of different VOC species.

Finally, we encourage the use of the data presented in this study to review the official inventory of the MCMA, and to support the application of photochemical models.

\section{Supplementary material related to this article is available online at: http://www.atmos-chem-phys.net/10/9027/2010/ acp-10-9027-2010-supplement.pdf.}

Acknowledgements. The authors acknowledge Emma Bueno for the continuous operation of the gas chromatograph. Toshiyuki Tanaka from Teikyo University of Science and Technology gave essential advice in the part of VOC analytics. Furthermore, we thank Luisa Molina, Matthew MacLeod, Sasha Madronich, Eric Velasco, as well as the three anonymous reviewers for their valuable comments on the manuscript.

Edited by: S. Madronich

\section{References}

Apel, E. C., Emmons, L. K., Karl, T., Flocke, F., Hills, A. J., Madronich, S., Lee-Taylor, J., Fried, A., Weibring, P., Walega, J., Richter, D., Tie, X., Mauldin, L., Campos, T., Weinheimer, A., Knapp, D., Sive, B., Kleinman, L., Springston, S., Zaveri, R., Ortega, J., Voss, P., Blake, D., Baker, A., Warneke, C., Welsh-Bon, D., de Gouw, J., Zheng, J., Zhang, R., Rudolph, J., Junkermann, W., and Riemer, D. D.: Chemical evolution of volatile organic compounds in the outflow of the Mexico City Metropolitan area, Atmos. Chem. Phys., 10, 2353-2375, doi:10.5194/acp-10-23532010, 2010.

Anzaldo, C. and Barrón, E. A.: La transición urbana de México, 1900-2005. In: Consejo Nacional de Población: La situación demográfica de México 2009, available at: http://www.conapo.gob. mx/publicaciones/sdm/sdm2009/04.pdf, 2009.

Arriaga-Colina, J. L., West, J. J., Sosa, G., Escalona, S. S., Ordúñez, R. M., and Cervantes, A. D. M.: Measurements of VOCs in Mex- 
ico City (1992-2001) and evaluation of VOCs and CO in the emissions inventory, Atmos. Environ., 38, 2523-2533, 2004.

Blake, D. R. and Rowland, S. F.: Urban leakage of liquefied petroleum gas and its impact on Mexico City Air Quality, Science, 269, 953-956, 1995.

Bravo, H., Sosa, R., Sánchez, P., Bueno, E., and González, L.: Concentrations of benzene and toluene in the atmosphere of the southwestern area at the Mexico City Metropolitan Zone, Atmos. Environ., 36, 3843-3849, 2002.

de Foy, B., Lei, W., Zavala, M., Volkamer, R., Samuelsson, J., Mellqvist, J., Galle, B., Martínez, A.-P., Grutter, M., Retama, A., and Molina, L. T.: Modelling constraints on the emission inventory and on vertical dispersion for $\mathrm{CO}$ and $\mathrm{SO}_{2}$ in the Mexico City Metropolitan Area using Solar FTIR and zenith sky UV spectroscopy, Atmos. Chem. Phys., 7, 781-801, doi:10.5194/acp-7781-2007, 2007.

Dollard, G. J., Dumitrean, P., Telling, S., Dixon, J., and Derwent, R. G.: Observed trends in ambiente concentrations of C2-C8 hydrocarbons in the United Kingdom over the period from 1993 to 2004, Atmos. Environ., 41, 2559-2569, 2007.

EC: Directive 2000/69/EC of the European Parliament and of the Council Relating to Limit Values for Benzene and Carbon Monoxide in Ambient Air, European Community, Official Journal of the European Communities, 2000.

Evans, J., Levy, J., Hammit, J., Santos Burgoa, C., and Castillejos, M.: Health benefits of air pollution control, in: Air Quality in the Mexico Megacity - An Integrated Assessment, edited by: Molina, M. J. and Molina, L. T., Kluwer Academic Publishers, Dordrecht/Boston/London, 2002.

Fortner, E. C., Zheng, J., Zhang, R., Berk Knighton, W., Volkamer, R. M., Sheehy, P., Molina, L., and André, M.: Measurements of Volatile Organic Compounds Using Proton Transfer Reaction - Mass Spectrometry during the MILAGRO 2006 Campaign, Atmos. Chem. Phys., 9, 467-481, doi:10.5194/acp-9-467-2009, 2009.

Gamas, E. D., Magdaleno, M., Díaz, L., Schifter, I., Ontiveros, L., and Álvarez-Cansino, G.: Contribution of Liquefied Petroleum Gas to Air Pollution in the Metropolitan Area of Mexico City, J. Air Waste Manage., 50, 188-198, 2000.

Gasca, J., Ortiz, E., Castillo, H., Jaimes, J. L., and González, U.: The impact of liquefied petroleum gas usage on air quality in Mexico City, Atmos. Environ., 38, 3517-3527, 2004.

Grutter, M., Flores, E., Andraca-Azala, G., and Báez, A.: Formaldehyde levels in downtown Mexico City during 2003, Atmos. Environ., 39, 1027-1034, 2005.

INE/SMA/UAM: Monitoreo y Evaluación de las Concentraciones de Compuestos Orgánicos Volátiles en la Zona Metropolitana de la Ciudad de México. Informe final, Instituto Nacional de Ecología, Secretaría de Medio Ambiente del Gobierno del Distrito Federal, Universidad Autónoma Metropolitana, Mexico City, 2006.

Jaimes-López, J. L., Sandoval-Fernández, J., González-Macías, U., and González-Ortiz, E.: Liquefied petroleum gas effect on ozone formation in Mexico City, Atmos. Environ., 37, 2327-2335, 2003.

Japanese Ministry of Environment: Environmental Quality Standards for Benzene, Trichloroethylene, Tetrachloroethylene and Dichloromethane, Notification on February 4th, available at: www.env.go.jp/en/air/aq/aq.html, 1997
Karl, T., Apel, E., Hodzic, A., Riemer, D. D., Blake, D. R., and Wiedinmyer, C.: Emissions of volatile organic compounds inferred from airborne flux measurements over a megacity, Atmos. Chem. Phys., 9, 271-285, doi:10.5194/acp-9-271-2009, 2009.

Lei, W., de Foy, B., Zavala, M., Volkamer, R., and Molina, L. T.: Characterizing ozone production in the Mexico City Metropoli$\tan$ Area: a case study using a chemical transport model, Atmos. Chem. Phys., 7, 1347-1366, doi:10.5194/acp-7-1347-2007, 2007.

Lei, W., Zavala, M., de Foy, B., Volkamer, R., and Molina, L. T.: Characterizing ozone production and response under different meteorological conditions in Mexico City, Atmos. Chem. Phys., 8, 7571-7581, doi:10.5194/acp-8-7571-2008, 2008.

Mohamed, M. F., Kang, D., and Aneja, V. P.: Volatile organic compounds in some urban locations in United States, Chemosphere, 47, 863-882, 2002.

Molina, M. J., Molina, L. T., West, J., Sosa, G., Sheinbaum Pardo, C., San Martini, F., Zavala, M. A., and McRae, G.: Air Pollution Science in the MCMA: Understanding Source-Receptor Relationships through emissions inventories, measurements, and modeling, in: Air Quality in the Mexico Megacity - An Integrated Assessment, edited by: Molina, M. J. and Molina, L. T. Kluwer Academic Publishers, Dordrecht/Boston/London, 2002.

Mugica, V.: Determinación de los perfiles de emisión de compuestos orgánicos volátiles en la ZMVM y su aplicación en el modelo CMB, Ph.D. Thesis, Universidad Nacional Autónoma de México, Mexico, 1999.

Mugica, V., Watson, J., Vega, E., Reyes, E., Ruiz, M. E., and Chow, J.: Receptor Model Source Apportionment of Nonmethane Hydrocarbons in Mexico City, The Scientific World, 2, 844-860, 2002.

Nguyen, H. T., Kim, K. H., and Kim, M. Y.: Volatile organic compounds at an urban monitoring station in Korea, J. Hazard. Mater., 191, 163-174, 2009.

R Development Core Team: R: A language and environment for statistical computing. R Foundation for Statistical Computing, Vienna, Austria, ISBN 3-900051-07-0, http://www.R-project.org, 2009.

SENER (Secretaría de Energía): Prospectiva del mercado de Gas LP 2009-2024, available at: http://www.sener.gob.mx/ webSener/res/PE_y_DT/pub/Prospectiva_gasLP_2009-2024.pdf, 2009a

SENER (Secretaría de Energía): Sistema de Información Energética, available at: http://sie.energia.gob.mx, 2009 b.

SMA (Secretaría de Medio Ambiente del Gobierno del Distrito Federal): La calidad del aire en la Zona Metropolitana del Valle de México, 1986-2006, 2007.

SMA (Secretaría de Medio Ambiente del Gobierno del Distrito Federal): Inventario de emisiones de contaminantes criterio de la Zona Metropolitana del Valle de México 2006, http://www.sma. df.gob.mx/sma/index.php?opcion=26 \\&id=501, 2008.

Song, J., Lei, W., Bei, N., Zavala, M., de Foy, B., Volkamer, R., Cardenas, B., Zheng, J., Zhang, R., and Molina, L. T.: Ozone response to emission changes: a modeling study during the MCMA-2006/MILAGRO Campaign, Atmos. Chem. Phys., 10, 3827-3846, doi:10.5194/acp-10-3827-2010, 2010.

Sosa, E. R., Bravo, A. H., Mugica, A. V., Sanchez, A. P., Bueno, L. E., and Krupa, S.: Levels and source apportionment of volatile organic compounds in southwestern area of Mexico City, Envi- 
ron. Pollut., 157, 1038-1044, 2009.

Stephens, S., Madronich, S., Wu, F., Olson, J. B., Ramos, R., Retama, A., and Muñoz, R.: Weekly patterns of México City's surface concentrations of $\mathrm{CO}, \mathrm{NO}_{\mathrm{x}}, \mathrm{PM}_{10}$ and $\mathrm{O}_{3}$ during 19862007, Atmos. Chem. Phys., 8, 5313-5325, doi:10.5194/acp-85313-2008, 2008.

Tang, J. H., Chan, L. Y., Chan, C. Y., Li, Y. S., Chang, C. C., Liu, S. C., Wu, D., and Li, Y. D.: Characteristics and diurnal variations of NMHCs at urban, suburban and rural sites in the Pearl River Delta and a remote site in South China, Atmos. Environ., 41, 8620-8632, 2007.

Tie, X., Madronich, S., Li, G., Ying, Z., Zhang, R., Garcia, A., LeeTaylor, J., and Liu, Y.: Characterization of chemical oxidants in Mexico City: A regional chemical dynamical model (WRFChem) study, Atmos. Environ., 41, 1989-2008, 2007.

US-EPA: Compendium method TO-14A, determination of volatile organic compounds (VOCs) in ambient air using specially prepared canisters with subsequent analysis by gas chromatography, US Environmental Protection Agency, Cincinnati, OH, 1999.

US-EPA: CMB8.2 user's manual, US Environmental Protection Agency, Research Triangle Park, NC, 2004.

Vega, E., Mugica, V., Carmona, R., and Valencia, E.: Hydrocarbon source apportionment in Mexico City using the chemical mass balance receptor model, Atmos. Environ., 34, 4121-4129, 2000.

Velasco, E., Lamb, B., Pressley, S., Allwine, E., Westberg, H., Jobson, T., Alexander, M., Prazeller, P., Molina, L., and Molina, M.: Flux measurements of volatile organic compounds from an urban landscape, Geophys. Res. Lett., 32, L20802, doi:10.1029/2005GL023356, 2005.

Velasco, E., Lamb, B., Westberg, H., Allwine, E., Sosa, G., ArriagaColina, J. L., Jobson, B. T., Alexander, M. L., Prazeller, P., Knighton, W. B., Rogers, T. M., Grutter, M., Herndon, S. C., Kolb, C. E., Zavala, M., de Foy, B., Volkamer, R., Molina, L. T., and Molina, M. J.: Distribution, magnitudes, reactivities, ratios and diurnal patterns of volatile organic compounds in the Valley of Mexico during the MCMA 2002 \& 2003 field campaigns, Atmos. Chem. Phys., 7, 329-353, doi:10.5194/acp-7-329-2007, 2007.

Velasco, E., Márquez, C., Bueno, E., Bernabé, R. M., Sánchez, A., Fentanes, O., Wöhrnschimmel, H., Cárdenas, B., Kamilla, A., Wakamatsu, S., and Molina, L. T.: Vertical distribution of ozone and VOCs in the low boundary layer of Mexico City, Atmos. Chem. Phys., 8, 3061-3079, doi:10.5194/acp-8-3061-2008, 2008.
Velasco, E., Pressley, S., Grivicke, R., Allwine, E., Coons, T., Foster, W., Jobson, B. T., Westberg, H., Ramos, R., Hernández, F., Molina, L. T., and Lamb, B.: Eddy covariance flux measurements of pollutant gases in urban Mexico City, Atmos. Chem. Phys., 9, 7325-7342, doi:10.5194/acp-9-7325-2009, 2009.

Volkamer, R., Molina, L. T., Molina, M. J., Shirley, T., and Brune, W. H.: DOAS measurement of glyoxal as an indicator for fast VOC chemistry in urban air, Geophys. Res. Lett., 32, L08806, doi:10.1029/2005GL022616, 2005.

West, J. J., Zavala, M. A., Molina, L. T., Molina, M. J., San Mart' $\imath$ n, F., McRae, G. J., Sosa-Iglesias, G., and Arriaga-Colina, J. L.: Modeling ozone photochemistry and evaluation of hydrocarbon emissions in the Mexico City metropolitan area, J. Geophys. Res., 109, D19312, doi:10.1029/2004JD004614, 2004.

WHO: Air quality guidelines for Europe, second edition, World Health Organization, Copenhagen, 2000.

Wöhrnschimmel, H., Márquez, C., Mugica, V., Stahel, W. A., Staehelin, J., Cárdenas, B., and Blanco, S.: Vertical profiles and receptor modeling of volatile organic compounds over Southeastern Mexico City, Atmos. Environ., 40, 5125-5136, 2006.

Zavala, M., Herndon, S. C., Slott, R. S., Dunlea, E. J., Marr, L. C., Shorter, J. H., Zahniser, M., Knighton, W. B., Rogers, T. M., Kolb, C. E., Molina, L. T., and Molina, M. J.: Characterization of on-road vehicle emissions in the Mexico City Metropolitan Area using a mobile laboratory in chase and fleet average measurement modes during the MCMA-2003 field campaign, Atmos. Chem. Phys., 6, 5129-5142, doi:10.5194/acp-6-5129-2006, 2006.

Zavala, M., Herndon, S. C., Wood, E. C., Onasch, T. B., Knighton, W. B., Marr, L. C., Kolb, C. E., and Molina, L. T.: Evaluation of mobile emissions contributions to Mexico City's emissions inventory using on-road and cross-road emission measurements and ambient data, Atmos. Chem. Phys., 9, 6305-6317, doi:10.5194/acp-9-6305-2009, 2009. 